\title{
The Impact of Working Capital Turnover on Jordanian Chemical Industries' Profitability
}

\author{
Lina Warrad \\ Department of Accounting, Faculty of Economic and Administrative Science, \\ Applied Science University, Jordan-Amman
}

Received 2014-02-08; Revised 2014-02-13; Accepted 2014-02-25

\begin{abstract}
The chemical industry is of long-term importance to the maintain development of local economies and consider the largest industrial sectors in Jordan in terms of the exports volume which accomplished JD $1049000 \mathrm{~S}$ in 2012. Working capital considers being a measure of company's efficiency and its shortterm financial health; moreover, it is a critical component for a business survival and a main item for the hall boost in profitability. While Chemical Industries plays a vital role in Jordanian economic and compose a large portion in the total local output; this study conduct to approve the impact of capital turnover as a measure of efficiency on Chemical companies' profitability expressed by Return On Assets (ROA). A simple liner regression applied to test a period 2009-2011 in order to conclude the extent of the impact of working capital turnover on Jordanian Chemical industries' profitability through Return On Assets (ROA). The study showed a significant impact of independent variable working capital turnover on dependent variable return on assets among Chemical Industries listed on Amman Stock Exchange during the period from 2009 to 2011.
\end{abstract}

Keywords: Working Capital Turnover, Return on Assets (ROA), Amman Stock Exchange (ASE)

\section{INTRODUCTION}

Activity ratio or asset utilization ratio which also known operating efficiency ratios are intended to measure how well accompany manages various activities, particularly hoe efficiently it manages its various assets. Activity ratios are analyzed as indicator of ongoing operational performance_how effectively assets are used by a company. These ratios reflect the efficient management of both working capital and longer term assets (CFA, 2012a).

Working capital turnover ratio gives us information about the utilization of working capital in terms of dollars of sales per dollars of working capital. (CFA, $2012 b)$ and it is one of the more important items to analyze firms' performance.

Profitability is the ability of a firm to generate earnings. Analysis of profit is of vital concern to stockholders because they derive revenue in the form of dividends (Gibson, 2012).
Return On Investment (ROI) measures the relationship between profits and the investment required to generate them. The Return On Assets (ROA) compares income with total assets. It can be interpreted in two ways. First, it measures management's ability and efficiency in using the firm's assets to generate equity. Second, it reports the total return accruing to all provides of capital, independent of the source of capital (White et al., 2003).

One of the most important requirements is to keep a balance between practicing daily activities and profitability, although this seems to be difficult issue for the management because the value of working capital differ among firms over periods depending on many factors, a firm can be very profitable when it can translate cash resulting from operations in the same cycle, otherwise, in order to continue it would need to borrow.

This paper will investigate the impact of operating efficiency presented by working capital turnover on the profitability expressed Return On Assets (ROA) using the data for 11 Jordanian chemical industries listed on 
Amman stock exchange for the period from 2009 to 2011 and the researcher will try to compare the results with the previous studies in order to approve the consistency with other different economies.

\section{PREVIOUS RESEARCH}

The effect of working capital on profitability was presented by Arshad and Gondal (2013) study which examined the cement sector in Karachi Stock Exchange for the period from 2004 to 2010. The study surveyed 21 listed cement companies and it revealed a significant negative effect of working capital on these firms' profitability.

Examining the effect of working capital on cement sectors' profitability in Pakistan was showed by Manzoor (2013) study which examined 20 listed cement companies in Karachi Stock Exchange during 10 years period from 2001 to 2010 . The paper used correlation matrix and multiple regressions. The study revealed a negative significant effect of working capital on cement sectors' profitability in Pakistan.

Analyzing the impact of working capital management on the manufacturing companies' profitability in Nairobi Stock Exchange was presented by Nzioki et al. (2013) study which used a multiple regression and correlation to analyze a nine listed companies on Nairobi Stock Exchange. The results suggested a positive relation between gross profit margin with average collection period and average payment period and a negative correlation with cash conversion cycle. The relationship between the number of days of inventory on hand with gross profit margin was insignificant.

The impact of working capital management on Bangladeshi textiles industries' profitability was examined by Rahman (2011) study which used Correlation Matrix and Regression analysis on a data collected by relied on annual reports and official records, also primary data collected through a questionnaire. The results showed a positive impact of working capital management on Bangladeshi textiles industries' profitability.

The effect of working capital management through the cash conversion cycle on 2628 companies' profitability in Tehran Stock Exchange was presented by Alipour (2011) study which used multiple regressions and Pearson's correlation. The results revealed a negative significant relation between number of days of sales outstanding and inventory turnover with profitability and a direct significant relation between number of days of accounts payables and profitability, also a negative significant relation between cash conversion cycle and profitability.

The effect of working capital management on non financial institutions' performance was presented by Azam and Haider (2011) study which surveyed 21 Kse30 index listed institutions and covered the period from 2001 to 2010. The study applied Canonical Correlation analysis and then showed a significant impact of working capital on firms' performance.

\section{HYPOTHESES}

For studying the impact of capital turnover on profitability expressed by Return On Assets (ROA) the researcher test the following hypotheses:

H1: There is no significant impact of independent variable working capital turnover on dependent variable return on asset

\section{RESEARCH METHODOLOGY}

This section presents research methodology adopted in this study. It explains sample selection criteria, variables of the study and research model, hypotheses.

\subsection{The Research Sample}

The study examines financial reports for 11 Jordanian Chemical Industries listed on the Amman Stock Exchange (ASE) for the period 2009- 2011

\subsection{Variables of the Study}

\subsubsection{Dependent Variable- Return on Asset (ROA)}

Return on Asset (ROA): Measures the firm's ability to utilize its assets to create profits by comparing profits with the assets that generate the profits.

It can be calculated as follow:

\section{Net Income}

\section{Average Total Assets}

In practice, however, the ROA measure is sometimes computed using either net income or earnings before tax as the numerator. Such post interest ROI ratios make leveraged firms appear less profitable by charging earnings for payments (interest) to some capital providers (lenders) but not others (stockholders). Pre interest ROI ratios in contrast, 
facilitate the comparison of firms with different degrees of leverage. Therefore, ROI ratios that use total assets in the denominator should always include total earnings before interest in the numerator. As interest is tax deductible, post-tax profit measures should add back net-of-tax interest payments.

\subsubsection{Independent Variable-Working Capital Turnover}

Working Capital Turnover: Working capital is defined as current assets minus current liabilities. Working capital turnover indicates how efficiently the company generates revenue with its working capital

It can be calculated as follow:

\section{Revenue}

\section{Average Working Capital}

Is a summary ratio that reflects the amount of operating capital needed to maintain a given level of revenue. Only operating assets and liabilities should be used to compute this measure. Short-term debt, marketable securities and excess cash should be excluded, as they not required for operating activities.

\subsection{Research Model}

In order to test the study hypotheses, the research model can be designed as follows:

\author{
Return on asset $=$ \\ $-0.381+6.684$ working capital turnover $+\mathrm{e}$
}

\subsubsection{Liner Regressions}

To test the research hypotheses SPSS program was used to prepare the table of Analysis Of Variance (ANOVA table) as shown in table below:

By reviewing the Table 1 above the researcher find that the $\mathrm{P}$ value $=\left(0.001^{\mathrm{a}}\right)<5 \%$ is highly significant and this supports the reject of the main null hypothesis.

There is a significant impact of independent variable working capital turnover on dependent variable return on assets

\section{$\mathrm{ROA}=-0.381+6.684$ working capital turnover $+\mathrm{e}$}

\section{STATISTICAL ANALYSIS}

This section presents the results of descriptive statistic for the study variables.

As can be seen from Table 2 that the comprehensive multiple project has highest mean ratio and the highest Standard Deviation.

As can be seen from Table 3 that the comprehensive multiple project has highest mean ratio and the Industrial Commercial and Agricultural has the highest Standard Deviation.

Table 1. ANOVA ${ }^{\mathrm{b}}$

\begin{tabular}{lcrrr}
\hline Model & Sum of squares & df & Mean square & F \\
\hline 1 Regression & 394.507 & 1 & 394.507 & $0.001^{\text {a }}$ \\
Residual & 817.118 & 31 & 26.359 & 14.967 \\
Total & 1211.626 & 32 & & \\
\hline
\end{tabular}

a. Predictors: (Constant), working capital turnover

b. Dependent variable: Return on assets

Table 2. Dependent variable; working capital turnover

\begin{tabular}{lrr}
\hline & Mean & Std deviation \\
\hline The industrial commercial and agricultural & 3.03 & 5.29 \\
Premier business and projects & 0.00 & 0.00 \\
Jordan chemical industries & -11.08 & -39.19 \\
Universal chemical industries & 0.76 & 0.83 \\
Industrial industries and match/JIMCO & 0.32 & 0.29 \\
Jordan sulpho-chemicals & 3.46 & 0.11 \\
National chlorine industries & 2.58 & 2.65 \\
Jordan industrial resources & 1.08 & 1.38 \\
Comprehensive multiple project & 22.81 & 1.40 \\
The Arab pesticides and veterinary drugs MFG & 2.85 & 1.40 \\
Intermediate petrochemicals industries & & 2.51 \\
\hline
\end{tabular}


Table 3. Independent variable; Return On Assets (ROA)

\begin{tabular}{lrc}
\hline & Mean & Std deviation \\
\hline The industrial commercial and agricultural & 3.03 & 7.74 \\
Premier business and projects & 0.00 & 2.29 \\
Jordan chemical industries & -11.08 & 5.02 \\
Universal chemical industries & 0.76 & 2.25 \\
Industrial industries and match/JIMCO & 0.32 & 3.57 \\
Jordan sulpho-chemicals & 3.46 & 1.79 \\
National chlorine industries & 2.58 & 0.28 \\
Jordan industrial resources & 1.08 & 1.40 \\
Comprehensive multiple project & 22.81 & 0.31 \\
The Arab pesticides and veterinary drugs MFG. & 1.40 & 0.90 \\
Intermediate petrochemicals industries & 2.85 & 0.66
\end{tabular}

\section{CONCLUSION}

This study is achieved to approve if there is a significant impact of working capital turnover on profitability presented by return on assets of 11 Chemical Industries companies listed on Amman Stock Exchange covering the period from 2009 to 2011 . The study used a simple liner regression to cover the study period to examine the extent the impact of working capital turnover on profitability expressed by Return On Assets (ROA) in Jordanian Chemical industries.

Through the analysis of main hypothesis, the researcher conclude a significant impact of independent variable working capital turnover on dependent variable return on assets among Chemical Industries listed on Amman Stock Exchange during the period from 2009 to 2011.

The study results approved the results of some previous studies such as Arshad and Gondal (2013) study and Manzoor (2013) study which revealed a significant negative effect of working capital on their firms' profitability. Also Rahman (2011) study and Azam and Haider (2011) study those revealed a significant positive impact of working capital turnover on profitability. In general most previous studies proved the existence of impact of working capital turnover on profitability whether positive or negative and these results compatible with the study result.

The researcher will develop the result of the paper in a Jordanian sector-wise comparing study, in order to investigate if the importance of every industrial sector in the total local output may make differences in results.

\section{REFERENCES}

Alipour, M., 2011. Working capital management and corporate profitability: Evidence from Iran. World Applied Sci. J., 12: 1093-1099.
Arshad, Z. and M. Gondal, 2013. Impact of working capital management on profitability a case of the Pakistan cement industry. Interdisciplinary J. Contemporary Res. Bus., 5: 384-390.

Azam, M. and S. Haider, 2011. Impact of working capital management on firms' performance: Evidence from non-financial institutions of KSE-30 index. Interdisciplinary J. Contemporary Res. Bus., 3: 943-947.

CFA, 2012a. Financial reporting and analysis. CFA, Program Curriculum.

CFA, 2012b. Financial reporting and analysis. SchweserNotes $^{\mathrm{TM}}$ for the CFA Exam.

Gibson, 2012. Financial Statement Analysis. 13th Edn.

Manzoor, H., 2013. Working capital management and profitability: Evidence from cement sector of Pakistan, listed on Krachi stock exchange. J. Bus. Admin. Manage. Sci. Res., 2: 215-223.

Nzioki, P.M., S.K. Kimeli, M.R. Abudho and J.M. Nthiwa, 2013. Management of working capital and its effect on profitability of manufacturing companies listed on Nairobi Securities Exchange (NSE), Kenya. Int. J. Bus. Finance Manage. Res., 1: 35-42.

Rahman, M., 2011. Working capital management and profitability: A study on textiles industry. ASA Univ. Rev., 5: 115-132.

White, G.I., A.C. Sondhi and D. Fried, 2003. The Analysis and Use of Financial Statements. 3rd Edn., Wiley, Hoboken, ISBN-10: 0471375942, pp: 767. 